\title{
EVALUATION OF MODIS NDVI AND RAINFALL RELATION OVER THE LAND USE AND LAND COVERS OF TAMIL NADU, INDIA
}

\author{
P.J. Prajesh ${ }^{1 *}$,Balaji Kannan ${ }^{2}$, S. Pazhanivelan ${ }^{3}$, R. Kumaraperumal ${ }^{3}$, K.P. Ragunath ${ }^{3}$ \\ ${ }^{1}$ M.Sc. (Ag.) Geoinformatics, Department of Remote Sensing and GIS, Tamil Nadu Agricultural University, Coimbatore, Tamil \\ Nadu, India. \\ ${ }^{2}$ Department of Soil and Water Conservation Engineering, Tamil Nadu Agricultural University, Coimbatore, Tamil Nadu, India. \\ ${ }^{3}$ Department of Remote Sensing and GIS, Tamil Nadu Agricultural University, Coimbatore, Tamil Nadu, India. \\ *Corresponding Author-iamprajesh17@gmail.com
}

Commission III, WG III/10

KEY WORDS: Land Use and Land Covers, Kharif season, MODIS, NDVI, Rabi Season, Rainfall, Vegetation change

\begin{abstract}
:
Vegetation is a part of terrestrial ecosystem that plays an important role in stabilizing global environment. Their needs to be a reliable information on the status of vegetation, which is needed for solving environmental problems. In this present study, vegetation growth and development were monitored over the land covets of Tamil Nadu, India during the crop growing season viz., Kharif season and Rabi season of 2017 using MODIS satellite derived surface reflectance product (MOD09A1) which is available at $500 \mathrm{~m}$ resolution and 8-days temporal period. Based on the surface reflectance data, NDVI was extracted for monitoring vegetation greening and browning. In order to correlate the relation between vegetation growth and influence of rainfall over the land covers, averaged seasonal rainfall was extracted from TRMM based rainfall product. It was noticed that NDVI response from the land covers showed a good range of temporal variations in vegetation biomass condition, however NDVI values appears to have increasing variations which indicated presence of high biomass intensity in Tamil Nadu. The seasonal NDVI response under nonvegetated/barren land class and moderate vegetation class was well related to shortage of dry spell and deficiency in precipitation that occurs due to abrupt changes in climate within the season. While the seasonal rainfall distribution over the land covers suggested that, compared to Kharif season, Rabi season received maximum amount of rainfall in Tamil Nadu during the cropping season of 2017. However, it was also observed that due fluctuation in intensity and duration of rainfall, the seasonal rainfall distribution over the land covers suggested that, compared to Kharif season, Rabi season received maximum amount of rainfall in Tamil Nadu during the cropping season of 2017.
\end{abstract}

\section{Introduction}

Temporal and spatial variations in vegetation distribution and growth require continuous evaluation of land use and land cover change detection. While land cover is becoming increasingly important, evaluation of land degradation remains to be a challenging task ( $\mathrm{Lu}$ et al., 2007). Changes in landscape dynamics for a sustainable management action requires better understanding of the variation within the ecosystem. The variations within the ecosystem can be attributed to the response of vegetation cover in terms of timing, duration and density to the inter-annual variations in climate (Stephenson, 1990).

Among the climatic factors that contribute to temporal and spatial; variations in vegetation, temperature and precipitation are the described to be most important factors (Yamaguchi, 2001). However, at broader scale, precipitation plays the dominant role in controlling the plant growth in drier part a region whereas temperature plays a domination role in colder regions in determining the vegetation growth (Martiny et al., 2006). While a monthly-derived data can be used can be suggested to reveal the relationship between vegetation indices and climate change variables, numerous studies have been carried out in the past to examine the relationship between vegetation variation and climate change at various temporal and spatial scale from years to decade
(Yang et al., 1998) and from region to global level (Nicholson and Farrar, 1994).

Monitoring the response of vegetation to inter seasonal climate change and short-term climate extremes, vegetation indices information acquired using remote sensing data that generates and gathers continuous land resource data at global and regional scales in digital forms, have seemingly been increasing. Longterm rainfall records, vegetation health condition, and land surface temperature data obtained from remote sensing-based methods can well be utilized for vegetation dynamic monitoring and modeling purposes. The multispectral bands are sensitive to biophysical parameters of vegetation such as chlorophyll content, water content and internal leaf structure. Based on these parameters spectral information, indices have developed such as EVI, SAVI, NDVI and NDWI to monitor vegetation. Vegetation indices such as NDVI, EVI and NDWI have been widely used to study the temporal changes in vegetation dynamics in various ecosystem types and at different spatial scales (Tucker, 1979; Gao 1996).

In this present study, NDVI (Normalized Difference Vegetation Index) which is one of the most commonly and widely used remote sensing based vegetation index (Rouse et al., 1974) was derived from MODIS satellite based Terra sensor for monitoring vegetation condition dynamics over the state of 
Tamil Nadu, India which has tropical savanna climate. While rainfall is a key climatic factor that controls dynamic changes in vegetation growth especially in arid and semi-arid regions as vegetation's in these areas are extremely susceptible to the quantity, duration and frequency of rainfall (Liu et al., 2012, Kundu et al., 2015), analyzing and identifying the pattern of rainfall and vegetation and its relationship is relevant towards studying the vulnerable conditions of tropical regions.

\section{Materials and Method}

\subsection{Study Site}

Tamil Nadu is situated in the South-Eastern part of Indian Peninsular region that lies between $8.5^{\circ} \mathrm{N}$ and $13.35^{\circ} \mathrm{N}$ latitude and $78.35^{\circ} \mathrm{E}$ and $80.20^{\circ} \mathrm{E}$ longitude (Fig. 1) with total area coverage of 13 Mha and coastline covering of $1076 \mathrm{~km}$ (Ramesh et al., 2008). The physiography of Tamil Nadu can be divided into four zones viz., Eastern Ghats, Western Ghats, Coastal Plains and the Central Plateau. The north-western, western and southern parts are hilly and rich in vegetation, with Western Ghats effectively blocking much of rain bearing clouds of South West Monsoon from entering the state. The eastern parts are fertile coastal plains and northern parts are a mix of hills and plains. The central and the south-central regions are arid plains and receive less rainfall than other regions.

The state is majorly rainfall dependent and receives rainfall from South-West monsoon that prevails from the month of June to September and North-East monsoon that prevails from the month of October to December. The average rainfall is $945 \mathrm{~mm}$ in which North-East monsoon contributes 48 per cent of rainfall while 32 per cent is contributed from the South-West monsoon (Gumma et al., 2014). The spatial distribution of rainfall over Tamil Nadu is highly variable and the coastal areas receives majority of rainfall while it decreases the inland areas. Also, the rainfall over the northern end is more than the southern locations, which can be related to the presence of maximum rainfall zones over the north eastern sectors.

\subsection{Land Use and Land Cover}

The land use and land cover classification data (Table 1) was generated from LISS III PAN Sharpened Image at 1:50,000 scales and a digital map were created that provided information about productive and non-productive regions and land of Tamil Nadu.

Out of the total geographical area in Tamil Nadu, the cultivable land that includes sown area, current fallow lands and other fallow lands occupied 58.2 per cent of total geographical area while the net sown area constituted of 36.20 per cent of total geographical area. The culturable land, which is defined as land, not cultivated but is available for cultivation accounted for 2.5 per cent of total geographical area.

\begin{tabular}{|c|l|c|}
\hline S.No. & \multicolumn{1}{|c|}{ Land Cover } & Area (sq. km.) \\
\hline 1. & Built-up & 5291.638 \\
\hline 2. & Cropland (Kharif) & 5232.520 \\
\hline 3. & Cropland (Rabi) & 13630.054 \\
\hline 4. & Forest-Deciduous & 8684.932 \\
\hline 5. & Forest- Evergreen & 5434.104 \\
\hline 6. & Forest-Swamp & 166.525 \\
\hline 7. & Forest-Scrub & 2559.801 \\
\hline 8. & Plantation Land & 9067.513 \\
\hline 9. & Wasteland & 5361.469 \\
\hline
\end{tabular}

\begin{tabular}{|c|l|c|}
\hline 10. & Water bodies & 8301.206 \\
\hline 11. & Wetland & 947.958 \\
\hline
\end{tabular}

Table 1. Area under different Land Use Land Cover of Tamil Nadu

\subsection{Processing of Satellite Data and Vegetation Index Extraction}

MODIS onboard terra sensor surface spectral reflectance product (MOD09A1) was downloaded as h25v7 and h25v8 gridded tiles for entire Tamil Nadu from the NASA developed earth data website (http://search.earthdata.nasa.gov) at 500meter spatial resolution and at 8-day temporal resolution. The pre-processing of the two gridded tiles was done using MODIS Reprojection Tool (MRT), where the two tiles (h25v7 and $\mathrm{h} 25 \mathrm{v} 8$ ) is mosaicked, reprojected from sinusoidal projection to Transverse Mercator projection and subsetted for the extent of Tamil Nadu. From the MRT processed image, NDVI was extracted for the time period between June 2017 to December 2017.

Inter annual variations of vegetation index values were considered for estimating the variations due weather fluctuation and the ecosystem component (Kogan, 1995). The extraction of NDVI was done using raster calculator based on NDVI formula (Equation 1) and considering the surface reflectance from two bands viz., red band and NIR band of MODIS surface reflectance product.

$$
\text { NDVI }=\frac{\rho(\text { NIR }- \text { RED })}{\rho(\text { NIR }+ \text { RED })}
$$

Equation 1

The extraction of NDVI value using raster calculator were represented in a value scale of -1 to +1 where in higher index values were associated with greater biomass, while the index value for bare soil, non-vegetated areas falls close to near 0 (Jeyaseelan, 2003). By computing the values of NDVI for 8-day interval Julian dates, monthly NDVI raster were generated using the maximum cell statistics for the Kharif and Rabi season of Tamil Nadu.

\subsection{Rainfall Data Collection and Analysis}

The behavior of climatic factor is one of the important aspects in vegetation dynamic that provides better understanding of vegetation development and degradation (Farrar et al., 1994). A global rainfall product (TRMM_3B42) based on Tropical Rainfall Measuring Mission (TRMM) was downloaded from Mirador web site (https://mirador.gsfc.nasa.gov) and utilized in netCDF format that provided estimates of rainfall gridded at $0.25^{\circ}$ by $0.25^{\circ}$ spatial resolution and 3 hours temporal resolution. From the TRMM_3B42 dataset, rainfall data was extracted for the region covering Tamil Nadu (latitude and longitude boundaries) and for the study period of June 2017 to December 2017.

\section{Results}

The different stages of crop health condition based on the vegetation biomass and chlorophyll concentration of different land covers, NDVI profile were grouped into five classes for Kharif season and Rabi season. 
The NDVI class were classified as non-vegetated land or barren land (NDVI less than 0$)$, poor vegetation greenness $(0.0$ to 0.2$)$ moderate vegetation greenness $(0.2$ to 0.4$)$, good vegetation greenness $(0.4$ to 0.6$)$ and dense vegetation greenness $(0.6$ to $1.0)$.

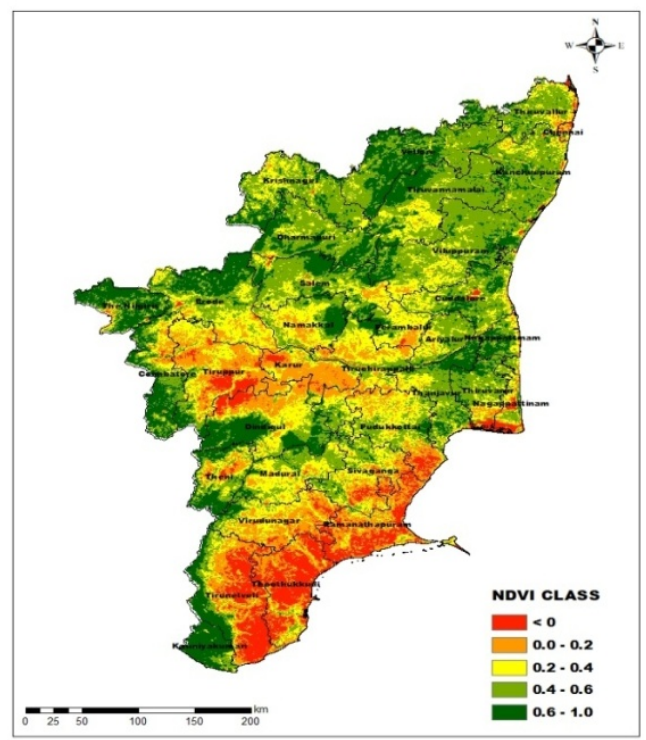

Fig. 1. Zonal Averaged NDVI Classes During Kharif Season of 2017 in Tamil Nadu

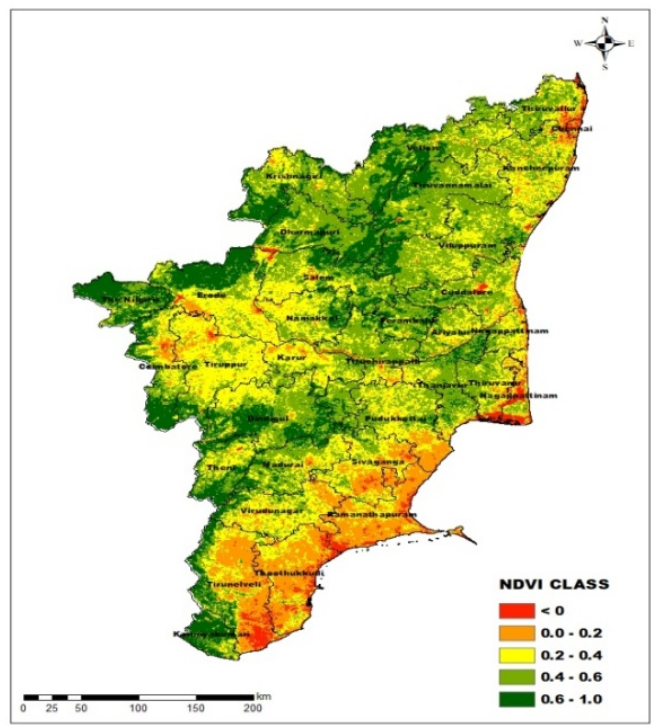

Fig. 2. Zonal Averaged NDVI classes During Rabi Season of 2017 in Tamil Nadu

\subsection{Seasonal NDVI Analysis}

During Kharif season (Fig. 1), it has been observed that 77.49 per cent of the forest areas fall under NDVI class of 0.6 to 1.0 (dense vegetation) indicating the greenery of forests is being maintained. While cropland (Kharif) shows 52.43 per cent of land possessing NDVI range of 0.4 to 0.6 (good vegetation) and 25.13 per cent of land under NDVI class 0.2 to 0.4 (moderate vegetation). The 17.85 per cent of swamp forest area is observed to have the NDVI class of less than 0 (non-vegetated or water bodies). The swamp forest area consisting of mangrove forests that are located along the coastal areas shows 43.32 per cent of the area under NDVI class of 0.0 to 0.2 (poor vegetation), where the available moisture tends to bring down NDVI values near to zero. In case of plantation land, out of the total available area 38.08 per cent of land showed NDVI class of 0.4 to 0.6 (good vegetation) followed by 32.75 per cent of land showing NDVI class of 0.6 to 1.0 (dense vegetation).

During Rabi season (Fig. 2), it has been observed that 96.32 per cent of the total area of forests and 77.32 per cent of scrub forest falls under NDVI class 0.6 to 1.0 (dense vegetation), indicating the greenery of forests is being maintained. The cropland (Rabi) shows a slight equal variation in the distribution of land area under good to dense vegetation conditions. It is observed that 31.62 per cent, 32.34 per cent and 35.89 per cent of land areas out of total cropland areas shows NDVI values between 0.2 to 0.4 (moderate vegetation), 0.4 to 0.6 (good vegetation) and 0.6 to1.0 (dense vegetation) respectively. In case of plantation land, majority of land area (58.85 per cent) has NDVI value greater than 0.6 indicating dense growth of plantation crops. While out the total swamp forest, 42.11 per cent of land falls under NDVI class of 0.6 to 1.0 (dense vegetation) and 34.65 per cent of land under NDVI class 0.4 to 0.6 (good vegetation).

\subsection{Season Averaged NDVI Profile}

During the Kharif season (Table 2), maximum NDVI $\left(N D V I_{\max }\right)$ is observed under forest area $(0.91)$ and the minimum NDVI $\left(\mathrm{NDVI}_{\min }\right)$ is observed under swamp forest areas (0.03). In case of cropland (Kharif) area, NDVI varied from $0.14\left(\mathrm{NDVI}_{\min }\right)$ to $0.85\left(\mathrm{NDVI}_{\max }\right)$. A similar variation of NDVI is observed for plantation land, where $\mathrm{NDVI}_{\max }$ is observed as 0.84 and $\mathrm{NDVI}_{\min }$ is observed as 0.17 . The mean NDVI value is recorded highest for the forest $(0.71)$ followed by scrubland (0.6), while the swamp forest shows least mean NDVI (0.35).

\begin{tabular}{|l|c|c|c|c|}
\hline \multicolumn{5}{|c|}{ Kharif Season } \\
\hline $\begin{array}{c}\text { Land } \\
\text { Cover }\end{array}$ & Min. & Max. & Mean & Coefficient of \\
Variation
\end{tabular}

Table 2. Zonal Averaged NDVI of Land Covers in Tamil Nadu during the Kharif season of 2017

The coefficient of variation (CV) is recorded highest for swamp forest (37.64 per cent), while the lowest CV was recorded for the forest (12.67 per cent), thus representing a constant vegetation development in forest area and indicating that the 
risk of getting poor vegetation condition is least. While the cropland displayed a lower CV value (19.08) which showed a lesser risk of poor vegetation growth during the Kharif season of 2017.

During the Rabi season (Table 3), maximum NDVI (NDVI $\left.\mathrm{max}_{\max }\right)$ is observed under forest area (0.90) and the minimum NDVI $\left(\mathrm{NDVI}_{\min }\right)$ is observed under swamp forest areas (-0.09). The occurrence of maximum NDVI in the forest can be attributed to the presence of perennial trees and natural vegetation (Traore $e t$ al., 2014). For cropland (Rabi) and plantation land, $\mathrm{NDVI}_{\max }$ $(0.84)$ is observed to be constant. The mean NDVI value is recorded highest for the forest (0.76) followed by scrub forest (0.68), while the swamp forest shows least mean NDVI (0.30).

\begin{tabular}{|l|c|c|c|c|}
\hline \multicolumn{5}{|c|}{ Rabi Season } \\
\hline $\begin{array}{c}\text { Land } \\
\text { Cover }\end{array}$ & Min. & Max. & Mean & Coefficient of \\
Variation
\end{tabular}

Table 3. Zonal Averaged NDVI of Land Covers in Tamil Nadu during the Rabi season of 2017

The coefficient of variation $(\mathrm{CV})$ is recorded highest for swamp forest ( 94.28 per cent) which may be attributed to growth of dense vegetation in some pockets of swamp forests and the lowest $\mathrm{CV}$ is recorded for the forest (8.47 per cent), thus representing a constant vegetation development in forest area. The cropland (Rabi) showed a CV value of 19.04 per cent and the plantation land shows a CV value of 14.79 per cent. In case of plantation land and scrub forest, the $\mathrm{CV}$ is observed to be 14.79 per cent and 13.94 per cent, which shows a minimum inter-seasonal variation under these land covers.

\subsection{Seasonal Rainfall Distribution}

The seasonal rainfall distribution over the land covers suggested that, compared to Kharif season, Rabi season received maximum amount of rainfall in Tamil Nadu during the cropping season of 2017.

During Kharif season (Table 4), maximum rainfall were received over cropland areas and scrubland $(296.82 \mathrm{~mm})$ followed by forest area which received maximum rainfall of $294.65 \mathrm{~mm}$. While it was noticed that during the same season variation in rainfall caused average rainfall received was highest for scrubland at $153.74 \mathrm{~mm}$ while the minimum average rainfall was observed over swamp forest $(103.64 \mathrm{~mm})$ followed by cropland with $199.96 \mathrm{~mm}$ of average rainfall.

\begin{tabular}{|l|c|c|c|}
\hline \multicolumn{4}{|c|}{ Kharif Season } \\
\hline Land Cover & Minimum & Maximum & Mean \\
\hline Cropland & 42.93 & 296.82 & 119.96 \\
\hline Plantation & 65.86 & 229.65 & 124.18 \\
\hline Forest & 49.04 & 294.34 & 146.75 \\
\hline Scrubland & 42.93 & 296.82 & 153.74 \\
\hline Swamp & 81.37 & 141.62 & 103.64 \\
\hline
\end{tabular}

Table 4. Zonal Averaged Rainfall over the Land Covers of Tamil Nadu during the Kharif season of 2017

During Rabi season (Table5), maximum rainfall was recorded over the cropland areas $(362.87 \mathrm{~mm})$ followed by swamp forest $(345.03 \mathrm{~mm})$. While due to variation in rainfall duration during the North-East monsoon, minimum amount of rainfall were recorded over scrubland and cropland areas. Overall, it was notice that the maximum average rainfall were received by swamp forest $(285.99 \mathrm{~mm})$ that are located near the coastal regions of Tamil Nadu. While plantation land $(126.50 \mathrm{~mm})$ received minimum average rainfall during the Rabi season of 2017 followed by forest area $(129.39 \mathrm{~mm})$.

\begin{tabular}{|l|c|c|c|}
\hline \multicolumn{4}{|c|}{ Rabi Season } \\
\hline Cropland & 0.0 & 362.87 & 137.10 \\
\hline Plantation & 34.77 & 269.56 & 126.50 \\
\hline Forest & 1.07 & 294.34 & 129.90 \\
\hline Scrubland & 0.0 & 296.82 & 139.39 \\
\hline Swamp & 73.06 & 345.03 & 285.99 \\
\hline
\end{tabular}

Table 5. Zonal Averaged Rainfall over the Land Covers of Tamil Nadu during the Rabi season of 2017

\section{Discussion}

In both the seasons it has been observed that, the percentage of pixels falling under forest areas shows NDVI class of 0.6 to 1.0 , indicating dense vegetation coverage within the forest ecosystem. The reason for increased NDVI values in the forest for both the season may be attributed to the perennial vegetation in the forest area, creating the ecosystem as high productive ecosystem (Quiring and Ganesh, 2010). During Rabi season, it has been noticed in case of swamp forest, which are majorly located near the southern coastal regions of Tamil Nadu there is a significant increase of vegetation greenness (dense vegetation). This can be related to similar observations carried by Bal et al. (2016), where the author suggested that coastal districts receives majority of North East Monsoon rainfall, whereas the interior districts receives lesser amount of rainfall.

While when compared to Kharif season, Rabi season showed better growth and development in land cover forms as majority 
of the land cover area is shown under NDVI class of 0.6 to 1.0 (dense vegetation). This improvement in terms of vegetation condition can very well be correlated to rainfall received during the months of October to December from the North East Monsoon season, which is the major provider of rainfall in Tamil Nadu (Nathan, 1998). While the lack of growth during the Kharif season can be attributed to the expansion of cropland areas and cropping intensification during the Kharif season and the current limits in the existing water resources (Milesi et al., 2010).

The inter-seasonal variability is relatively minimized in forest and cropland; as a result, vegetation growth is relatively stable and remains unaffected by the environmental factors (Mora and Arriagada, 2016). The NDVI fluctuation in Rabi season for the forest is found to be more sensitive compared to Kharif season that can be related to vegetation health and high biomass development during Rabi season (Huete et al., 2002).The occurrence of maximum NDVI in the forest might be due to the presence of perennial trees and natural vegetation while the variation in cropland (Kharif) can be due to the type of crops cultivated during the Kharif season (Traore et al., 2014).

Overall, it is noticed that irrespective of the season (Kharif and Rabi), the CV value for swamp forest is recorded the highest and the $\mathrm{CV}$ value for the forest is recorded the lowest. However, the cropland (Kharif and Rabi) shows almost similar interseasonal variability during both the season. This little variation in the croplands during Kharif season and Rabi season may attribute to the abrupt changes in rainfall that influence the vegetation growth (Hussein et al., 2017).

\section{Conclusion}

The NDVI response over the land covers of Tamil Nadu showed a good range of temporal variation in vegetation biomass condition, however NDVI values appears to have increasing variations which indicates presence of high biomass intensity in Tamil Nadu. It was noticed that NDVI due to its simplicity in calculation, easy interpretation and global use could be largely utilized for monitoring vegetation greenness and browning. In terms of vegetation change, seasonal NDVI response under nonvegetated/barren land category and moderate vegetation category is very well related to shortage of dry spell and deficiency in precipitation that occurs due to abrupt rainfall changes within the seasons.

The occurrence of dense vegetation conditions in the land covers of Tamil Nadu is attributed to the presence of crop diversification and possible changes in habitat characteristics along with the presence of perennial vegetation within the ecosystem. However, it was also noticed that vegetation growth and decline over the land covers was not much related to rainfall, which was not unique either throughout the cropgrowing season or between the land covers of Tamil Nadu. This suggested that rainfall could not be considered as the major key factor in deciding the vegetation growth and development in many land covers of Tamil Nadu.

\section{Acknowledgment}

This study was carried out through the Junior Research Fellowship funded during October 2017- June 2018 by The Department of Remote Sensing and GIS, Directorate of Natural Resource Management, Tamil Nadu Agricultural University,
Coimbatore, India under the NADP (RKVY) Scheme on "Remote Sensing based information for crop coverage, yield estimation and drought monitoring".

\section{References}

Bal, P. K., A. Ramachandran, R. Geetha, B. Bhaskaran, P. Thirumurugan, J. Indumathi and N. Jayanthi. 2016. Climate change projections for Tamil Nadu, India: deriving highresolution climate data by a downscaling approach using PRECIS. Theoretical and Applied Climatology, 123(3-4), pp. 523-535.

Gao, B. C. 1996. NDWI - A normalized difference water index for remote sensing of vegetation liquid water from space. Remote Sensing of Environment, 58(3), pp. 257-266. https://doi.org/10.1016/S0034-4257 (96)00067-3.

Gumma, M. K., P. S. Thenkabail, A. Maunahan, S. Islam and A. Nelson. 2014. Mapping seasonal rice cropland extent and area in the high cropping intensity environment of Bangladesh using MODIS $500 \mathrm{~m}$ data for the year 2010. International Journal of Photogrammetry and Remote Sensing, 91, pp. 98113. https://doi.org/10.1016/j.isprsiprs.2014.02.007.

Huete, A., K. Didan, T. Miura, E. P. Rodriguez, X. Gao and L. G. Ferreira. 2002. Overview of the radiometric and biophysical performance of the MODIS vegetation indices. Remote sensing of environment, 83(1-2), pp. 195-213. https://doi.org/10.1016/S0034-4257(02)00096-2.

Hussein, S. O., F. Kovács and Z. Tobak. 2017. Spatiotemporal assessment of vegetation indices and land cover for Erbil city and its surrounding using MODIS imageries. Journal of Environmental Geography, 10(1-2), pp. 31-39. https://doi.org/10.1515/jengeo-2017-0004.

Jeyaseelan, A. T. 2003. Droughts\& floods assessment and monitoring using remote sensing and GIS. In Training workshop of Satellite remote sensing and GIS applications in agricultural meteorology, pp. 291-313.

Kogan, F. N. 1995. Application of vegetation index and brightness temperature for drought detection. Advances in Space Research, 15(11), pp. 91-100. https://doi.org/10.1016/0273-1177 (95)00079-T.

Kundu, A., D. M. Denis and N, R. Patel. 2015. Evaluation of the meteorological drought over the Bundelkhand region using geo-spatial techniques. Climate Change, 1(4), pp. 418-424.

Liu, X., X. Zhu, Y. Pan, S. Li, Y. Liu and Y. Ma. 2016. Agricultural drought monitoring: Progress, challenges, and prospects. Journal of Geographical Sciences, 26(6), pp. 750767.

Lu, D., M. Batistella, P. Mausel and E. Moran. 2007. Mapping and monitoring land degradation risks in the Western Brazilian Amazon using multitemporal Landsat TM/ETM+ images. Land Degradation \& Development, 18(1), pp. 41-54. https:// $\underline{\text { doi.org/10.1002/ldr.762 }}$

Martiny, N., P. Camberlin, Y. Richard and N. Philippon. 2006. Compared regimes of NDVI and rainfall in semi-arid regions of 
Africa. International Journal of Remote Sensing, 27(23), pp. 5201-5223. https:// doi.org/10.1080/01431160600567787.

Milesi, C., A. Samanta, H. Hashimoto, K. K. Kumar, S. Ganguly, P.S. Thenkabail, A. N. Srivastava, R. R. Nemaniand R. B. Myneni. 2010. Decadal variations in NDVI and food production in India. Remote Sensing, 2(3), pp. 758-776. https:// doi: $10.3390 / \mathrm{rs} 2030758$.

Mora, F. and O. Arriagada. 2016. A classification proposal for coefficients of variation in Eucalyptus experiments involving survival, growth and wood quality variables. Bragantia, 75(3), pp. 263-267. https://doi.org/10.1590/1678-4499.458.

Nathan, K. K. 1998. Droughts in Tamil Nadu: A qualitative and quantitative appraisal. Drought Network News (1994-2001), pp. 62.

Nicholson, S. E., and T.J. Farrar. 1994. The influence of soil type on the relationships between NDVI, rainfall, and soil moisture in semiarid Botswana. I. NDVI response to rainfall. Remote Sensing of Environment, 50(2), pp. 107-120. https:// doi.org/10.1016/0034-4257 (94)90038-8.

Quiring, S. M. and S. Ganesh. 2010. Evaluating the utility of the Vegetation Condition Index (VCI) for monitoring meteorological drought in Texas. Agricultural and Forest Meteorology, 150(3), pp. 330-339. https:// doi.org/10.1016/j.agrformet.2009.11.015.

Ramesh, R., P. Nammalwarand, V. S. Gowri. 2008. Database on coastal information of Tamilnadu. Report to Environmental Information System (ENVIS), Department of Environment, Government of Tamil Nadu.

Rouse, J., R. H. Haas, J. A. Schell and D. W. Deering, 1974. Monitoring vegetation systems in the Great Plains with ERTS. In $3^{\text {rd }}$ ERTS-1 Symposium, 1, pp. 309-317.

Stephenson, N. 1998. Actual evapotranspiration and deficit: biologically meaningful correlates of vegetation distribution across spatial scales. Journal of Biogeography, 25(5), pp. 855870. https://doi.org/10.1046/j.1365-2699.1998.00233.x.

Traore, S. B., A. Ali, S. H. Tinni, M. Samake, I. Garba, I. Maigari and P. O. Dieye. 2014. AGRHYMET: A drought monitoring and capacity building center in the West Africa Region. Weather and Climate Extremes, 3, pp. 22-30. https:// doi.org/10.1016/j.wace.2014.03.008.

Tucker, C. J. 1979. Red and photographic infrared linear combinations for monitoring vegetation. Remote Sensing of Environment, 8(2), pp. 127-150. https:// doi.org/10.1016/00344257 (79)90013-0.

Yang, L., B. K. Wylie, L. L. Tieszen and B. C. Reed. 1998. An analysis of relationships among climate forcing and timeintegrated NDVI of grasslands over the US northern and central Great Plains. Remote Sensing of Environment, 65(1), pp. 25-37. https:// doi.org/10.1016/S0034-4257 (98)00012-1. 